\title{
Using Technology in Teaching
}





\section{Using Technology in Teaching}

William Clyde and Andrew Delohery 
Copyright (C) 2005 by Yale University.

All rights reserved.

This book may not be reproduced, in whole or in part, including illustrations, in any form (beyond that copying permitted by Sections 107 and 108 of the

U.S. Copyright Law and except by reviewers for the public press),

without written permission from the publishers.

Designed by Sonia Shannon.

Set in Bulmer type by Integrated Publishing Solutions.

Printed in the United States of America by Sheridan Books.

Library of Congress Cataloging-in-Publication Data

Clyde, William.

Using technology in teaching / William Clyde

and Andrew Delohery.

p. $\mathrm{cm}$.

Includes bibliographical references and index.

ISBN 0-300-10394-8 (pbk. : alk. paper)

1. Education, Higher-Computer-assisted instruction. 2. College

teaching-Aids and devices. 3. Educational technology. I. Delohery,

Andrew. II. Title.

LB2395.7.C59 2004

$378.1^{\prime} 7344678-\mathrm{dc} 22$

2004023495

A catalogue record for this book is available from the British Library.

The paper in this book meets the guidelines for permanence and durability of the Committee on Production Guidelines for Book Longevity of the Council on Library Resources.

$\begin{array}{llllllllll}10 & 9 & 8 & 7 & 6 & 5 & 4 & 3 & 2 & 1\end{array}$ 
To my dear wife

-W. C.

To Jodie, whose sensibilities make all things possible - A. D. 
